\title{
Post-Translational Regulation
}

National Cancer Institute

\section{Source}

National Cancer Institute. Post-Translational Regulation. NCI Thesaurus. Code C19903.

Post-T ranslational Regulation is controlled biochemical alteration of proteins involving generally reversible covalent modification or irreversible processing to regulate activity, location, or stability. 